\title{
Metastatic Paranasal Sinus Squamous Cell Carcinoma
}

National Cancer Institute

\section{Source}

National Cancer Institute. Metastatic Paranasal Sinus Squamous Cell Carcinoma. NCI

Thesaurus. Code C162876.

Paranasal sinus squamous cell carcinoma that has spread from its original site of growth to another anatomic site. 